\title{
Financing models of vocational education and its impact on the economy: Problems and perspectives
}

\author{
George Abuselidze ${ }^{1,}$ and Lasha Beridze ${ }^{2}$ \\ ${ }^{1}$ Batumi Shota Rustaveli State University, Ninoshvili street 35. Batumi, Georgia \\ ${ }^{2}$ St. Tbel Abuseridze University, Khulo, Georgia
}

\begin{abstract}
Vocational education and related financial support are one of the priorities of the countries policy at the present stage. Education is the fundamental foundation that is necessary for development of the world. While the deterioration of the socio-economic situation in transition in Georgia, inadequate economic policies, the adoption of inappropriate employment decisions, the use of models used by developed countries, and many others, caused the departure of vocational education space in the country. In the survey is studied vocational education financing models of developed countries and the education policy of Georgia. The research process uses the qualitative and quantitative method of data collection. The work is undertaken in depth research of the current model of funding of vocational education programs, analysis and relevant conclusions.
\end{abstract}

\section{Introduction}

The financing of initial and continuing vocational training contains a monetary and institutional-organizational aspects. The monetary aspect attempts to quantify the amounts allocated for funding in a differentiated manner according to the different funders, i.e. the State, the company, individuals, and according to public and private budgets. Through the enumeration of types of costs and funders a comprehensive picture of the overall financing system is given [11].

The institutional-organizational aspect primarily focuses on the procedures - mutually agreed through a balance of interests between those participating in vocational training (State, employers' associations and trade unions) via political opinion-building and decision-making - of resource collection, resource use and resource administration with the aim of achieving the targeted vocational training goals established through consensus.

An examination of the funding system requires a fusion of the two aspects with the following result: financial resources are provided from current or future income or revenue in the form of institutional or individual support via market-driven, rule-bound, contractually stipulated or administratively planned provision of funds and payments based

\footnotetext{
*Corresponding author: abuseri@mail.ru / george.abuselidze@bsu.edu.ge
} 
on the equivalence principle, or with distribution effects or relief of cost burden via public budgets which are not always completely transparent [11].

Because of incomplete data, surveys of the financing of initial and continuing vocational training already encounter partially unresolvable problems at national level; furthermore, in the case of bilateral or multilateral comparative analysis, considerable gaps are to be found in the data on the institutional functioning of highly diverse financing systems. This is also one of the reasons for development of incompatible methods of effectiveness assessment.

Funding systems for vocational training developed historically. Their characteristic institutional-organizational structures are influenced by socio-economic frame conditions and philosophical-cultural background factors.

Scientific considerations connected with financing of vocational education, are mainly determined with actuality originated as a result of public debates. Correspondingly, the scientifically developed and submitted proposals require political decisions, what complicates renewal and implementation of the theoretical and practical activities.

\section{Stating of problem and methodology}

\subsection{Benefits of vocational education for individuals}

The main private market benefits of education and training for individuals are higher wages, improved job and career prospects, also known as employability [14, 15, 18]. Evidence that initial education increases personal income is available from many studies covering many years and from over 100 countries with different cultures and economic systems $[1,16]$.

For continuing VET, research surveyed has focused on remedial government-paid offthe-job training programmes and employer-paid training. Evidence on remedial training, largely for unemployed or long-term unemployed people, suggests only limited success [23]. Some studies show that labour market training programmes can raise wages, while others show their effects to be insignificant. Given diversity of such programmes and their target groups, it is unsurprising that results are mixed. However, there is considerable evidence that employer-paid continuing VET does raise wages. In contrast to homogeneity character ising wage returns on initial education, there is no sign that returns on VET are harmonised across countries. Large positive effects on wages have been found in the UK $[4,10,17]$. Studies for other European workers are more mixed, but still typically positive. Groot et al. [21] and Björklund [12] find large positive effects for Dutch and Swedish workers respectively, but Pischke [45] finds substantially smaller effects for German workers. Westergard-Nielsen (1993) and Goux and Maurin (2000) find effects close to zero for Danish and French workers respectively [20].

\subsection{Vocational education benefits for organizations}

Nowadays the organizations invest in human capital as they think that this should result better performance. This is proved with 66 US studies which assessed training to be related to performance measures, especially operational measures, such as customer satisfaction, or innovation. Training may increase productivity, but also wages at the same time. If wages rise faster than productivity, profitability will fall.

For Europe there is considerable evidence that firms investing in adult learning increase productivity. Studies in Austria, Denmark, Norway and Sweden have also found a positive 
link between continuing VET and improved organizational productivity and technological innovation [30].

Cedefop furthered the analysis by reviewing 62 studies on the empirical relationship between employer-provided training and productivity gains. The review was complicated because organizations and researchers measured training in many different ways: in terms of training expenses, in terms of share of employees who participated in training, or in terms of extent of conducting of trainings by the companies.

\subsection{Vocational education benefits for countries}

Many studies find a strong relationship between human capital stock and GDP per capita growth $[6,9,7,22,19,8,26,13]$. However, very few analyse how different levels of education, for example higher education or different types of general and vocational education, contribute to economic growth. Research on human capital's impact on national economic performance invariably meets the problem that, as intangible assets, skills are difficult to measure.

Consequently, Cedefop launched research to identify macroeconomic benefits of VET by developing a new skills measure that takes account of certified and uncertified skills and complementarities between them for seven Member States- Denmark, Germany, Spain, France, the Netherlands, Sweden and the UK [31]. The study analyses relationships between labour productivity and different types of skill.

The seven countries were chosen for their diverse VET systems. Some, such as Germany, have highly developed apprenticeship training, others, such as Sweden provide VET through full-time vocational schooling.

At national level, in is significant to link the skills contribution to labour productivity which grew between 1980 and 2007 and came through build-up of skills, most importantly higher-level skills (bachelor degree and above, ISCED 5a to 6). However, in six of the seven countries, upper-intermediate (technician level, ISCED 4 and5b) and lowerintermediate (craft level, ISCED 3A and 3B with vocational orientation) vocational skills also made positive contributions to labour productivity growth in some time periods. The exception is Germany where the lower intermediate vocational employment share was already high in 1980 and has not grown much since. In Denmark and the Netherlands, accumulation of lower intermediate vocational skills contributed more to growth in the 1980s and 1990s than higher qualifications. University-level skills, many of which are vocational, have a positive impact on average labour productivity in countries like France and the UK, where the dual system is less developed.

A strong skills base may generate technological developments or promote adoption of new technologies. Krueger and Kumar [27] found that while higher education can increase innovative capacity, investment in VET can improve a country's capacity to implement innovation.

To achieve higher productivity countries need both high- and intermediate-level vocational qualifications. One skill type is not more effective than the other; both are needed to generate higher productivity.

For example, rise in lower intermediate vocational skills combined with rise in upper intermediate skills is estimated to have increased trend productivity in Spain and the Netherlands by 3.5 to $4 \%$. In terms of GDP growth, estimated effects of similar increases in lower intermediate and upper intermediate skills provided through initial VET are highest in Germany and Spain, with GDP rising by about 1.5 to $2.5 \%$. They are lower in Sweden and the UK, where output increases by about $0.75 \%$. Skill increases also tend to reduce unemployment in all researched countries [31]. 


\section{Determinants of vocational education funding systems}

\subsection{The mechanism of the funding of vocational education in different countries}

In countries in which vocational training activities essentially depend on more or less autonomous decision processes in the companies, a scientific examination of the funding of vocational training is undertaken mostly from the economic angle (an example of this in Germany is the work of the Expert Commission on the Costs and Financing of Vocational Training undertaken in 1974).

In all countries of the European Union the State, companies and individuals finance different shares of initial and continuing vocational training by assuming different proportions of direct and indirect costs in mixed systems. That is why the term "cofinancing" or "co-investment" is used in this connection.

Vocational training does not have the same status in the different European countries. There is a general tendency to give it less importance than general education paths leading to higher levels of education. This discrimination is offset by the mutual realization that it should play an important role in the solution of economic, social and labour market problems. A broad range of measures providing financial support for vocational qualification processes for youth or for the creation, adaptation, improvement or enhancement of the vocational qualifications of employed or unemployed persons in the form of State programmes or on the basis of agreements between employers and trade unions, is oriented to the goal of reducing current unemployment and combating imminent unemployment and thus making a contribution to the securing or the increase of the performance capacity and competitivity of the economy.

The political reaction to the changed frame conditions in vocational education and training resulting from globalization, technological change and the internationalization of labour markets, is the reform or even a total shift from traditional financing systems. In most cases, however, deficits in the system are compensated or mitigated through ad hoc programmes.

Various financing strategies are practised in different parts of the world. Some of the more well known mechanisms for financing VET have been categorized in the following four types:

1. Public Financing

2. Enterprise Financing

3. Private and Public Sponsored Financing

4. International Donor Assistance.

Public Financing is provided through public revenue (government funds). When the State finances vocational training through public funds it is on the assumption that the ultimate responsibility for development of human resources for national development lies with the State.

In most countries the budget for VET from public sources is relatively small, ranging from 1 to $12 \%$ of the current expenditure on education [33]. For the last decade the growing tendency of increase in financing education sphere by the state can be traced. However, the share of expenses in education sphere within the entire product as well as in the state budget is significantly low. We think that in mid-term period financing of education will be considered as a priority direction in Georgia and minimum $1.5 \%$ of GDP and 3\% of state budget will be allotted for higher education financing and research [3].

Mostly public financed vocational training programmes are implemented in schools before employment is taken up. Non-formal training centres, pre-service and in-service training for Ministries also receive public funding. 
Specialized vocational training institutions receive public funds mainly through subsidies, budget appropriations, tax incentives, financing of development projects etc. In developing countries e.g. Pakistan, India and Thailand the main financial contribution for VET comes from public funds (government). In cases of mixed funding, generally capital expenditure is provided by the governments and recurring expenditure is shared through other sources.

When governments finance vocational training institutions they control the volume of resources allocated to VET in accordance with the priorities of the social and economic sectors (Ducci, 1991) [33]. They are also able to exercise control on the quality of the programmes. The cost effectiveness of vocational training through public financing is said to be low as public training institutions are not very keen to evaluate the qualitative and quantitative training needs. In Argentina, CONET receives funding from the Ministry which has been declining over the years due to a reduction in the overall budget of the ministry. There are restrictions on CONET securing funds from other sources e.g. sale of services, international sources and this has led to a serious shortage of resources affecting the efficiency of the institution in maintenance of infrastructure and equipment and reduction in staff salaries (Ducci, 1991) [33].

When public training institutions are expanded and do not get adequate finances correspondingly the quality of training may become poor. In Egypt government enrolls more than half of upper secondary students in vocational schools to divert them from higher education [33].

When VET is financed through the State it controls the curriculum, certification, qualification of teachers [33].

Japan is well known for its vocational training organized within large private companies. Employers prefer to recruit fresh school leavers with general education and then provide them with continuous training within the enterprise. The public sector is generally small. In 1980's it employed 3.6\% of the labour force [33]. Private industry employs $85 \%$ of the labour force and is dominated mainly by large industrial companies.

Most large companies organize their own vocational training and the outlays for inhouse vocational training are considered a part of the labour costs. Smaller companies with less resources rely on training facilities outside the company and are supported financially from proceeds of the unemployment insurance funds to which the government and employers contribute half and half. Enterprises can also pay to get membership of outside training organisations and can thus use their facilities for training of trainers. Vocational training is also organized outside the companies in special vocational schools run by various Ministries. Private vocational schools offer courses of varying duration including day and evening courses. These schools get grants from the government if they are not run for profit.

Most technical training in companies takes place in close connection with production. Production engineers train a small group of workers who will use the latest technology [43]). The Japan Industrial and Vocational Training Association (JIVTA) is the main organization in Japan concerned with training within industry. It is a private association of employers and has a constitution and a budget supervised by the Ministry of International Trade and Industry.

In Germany the 16-19 year olds receive training within the dual training system [33]. The system is called dual because there are two places of learning - the vocational schools and the companies. The training is governed by training regulations of the Vocational Training Act, 1969. The system offers a combination of training in vocational schools with learning and practical experience at the worksite. In a week, apprentices spend 1 or 2 days at the public vocational high schools where training in general subjects is offered. The 
remaining part of the week is spent on the job in the firm/enterprise. Training is usually for three and a half years after which individuals get certification and are free to get jobs.

The dual system sets high standards of training which leads to high productivity and competitiveness of the labour force. This is why the workers and employees trained in the system are highly appreciated by the German society [46] (Figure 1).

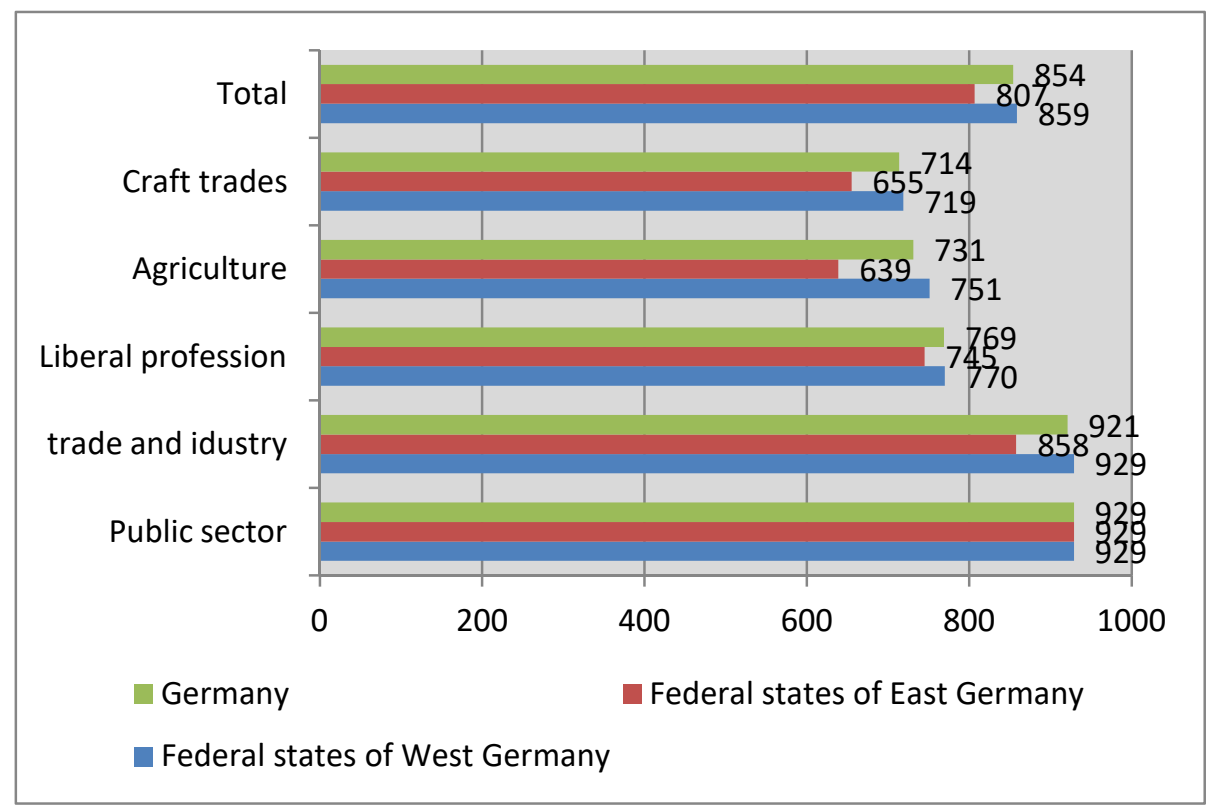

Fig.1. Training allowances based on collective wage agreements in 2016 by training areas - average gross monthly amounts in $€$

Source: author's calculations based on Calculations by the Federal Institute for Vocational Education and Training, VET Data Report Germany 2016/2017

In Estonia VET is provided at upper secondary and post-secondary levels. VET programme also is assessable for students who has not completed secondary education. Currently more and more students participate in general and continuing vocational education. There are $80 \%$ of state vocational educational institutions, also there are private and municipal educational institutions.

In $201671.1 \%$ of students studied in the comprehensive schools and $26.2 \%$ continued education in vocational institutions. The aim is to raise this index up to $35 \%$ (Drawing N 2).

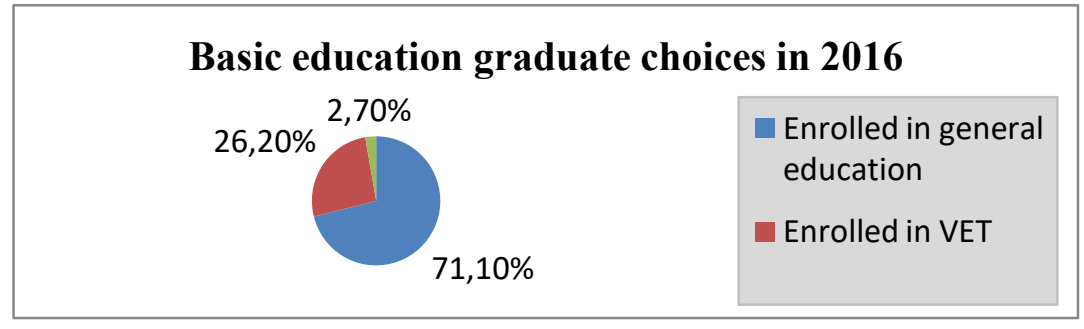

Fig. 2. Basic education graduate choices in 2016

Source: author's calculations based on European Center for Vocational Education, Review of Vocational Education System of Estonia 
It is also interesting to present general costs and investments into vocational education provided by the government of Estonia. As we have also mentioned, funding of vocational education in Estonia is mainly public, but there are also municipal and private vocational school there. It is important to point that in the period from 2008 to 2014 just 2010 was outstanding, as funding totaled 129 million Euro, but in 2014 it dropped to 108.7 million Euro, what was caused with decrease of investments into infrastructure and equipment using in implementation of VET investment projects (Diagram N 1).

Schedule 1. VET total expenditure and investments in 2008-14, Euro millions

\begin{tabular}{|c|c|c|c|c|c|c|c|}
\hline & 2008 & 2009 & 2010 & 2011 & 2012 & 2013 & 2014 \\
\hline VET costs & 85 & 98 & 129 & 118 & 108 & 105.2 & 108.7 \\
\hline $\begin{array}{l}\text { Investments (\% } \\
\text { of total VET } \\
\text { expenditures) }\end{array}$ & $6 \%$ & $26 \%$ & $40 \%$ & $33 \%$ & $30 \%$ & $17 \%$ & $19 \%$ \\
\hline
\end{tabular}

Source: author's calculations based on European Center for Vocational Education Development

\subsection{Cost of VET programmes in the European community}

In the EU countries the basic and continuing vocational education is regularly being analyzed, what allows States and supervising bodies more effectively determine the world market demands and make adequate response thereto. It is also important that companies providing regular refreshing of employees are directly involved into the vocational education process often contributing enough considerable funds, but, as we mentioned, such investments shall results rise of productivity and return the expenses.

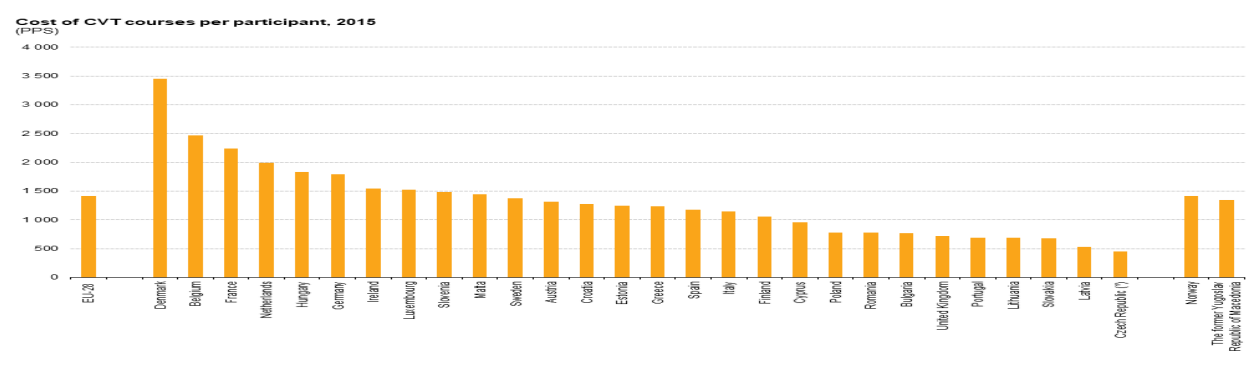

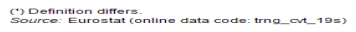

Fig. 3. Cost of CVT courses per participant

Source: European Community Statistics Service [online] https://ec.europa.eu/eurostat/statisticsexplained/images/c/c9/Cost_of_CVT_courses_per_participant\%2C_2015_\%28PPS\%29_ET18_II.png Figure 4: Enterprises employing IVT participants 


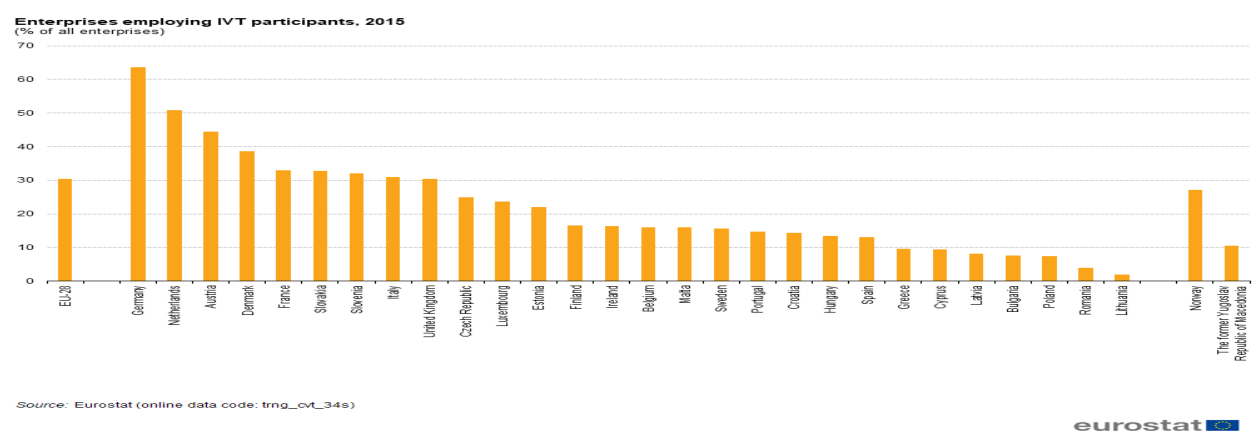

Fig. 4. Enterprises employing IVT participants

Source: European Community Statistics Service [online] https://ec.europa.eu/eurostat/statisticsexplained/images/6/67/Enterprises_employing_IVT_participants\%2C_2015_\%28\%25_of_all_enterpr ises\%29_ET18_II.png

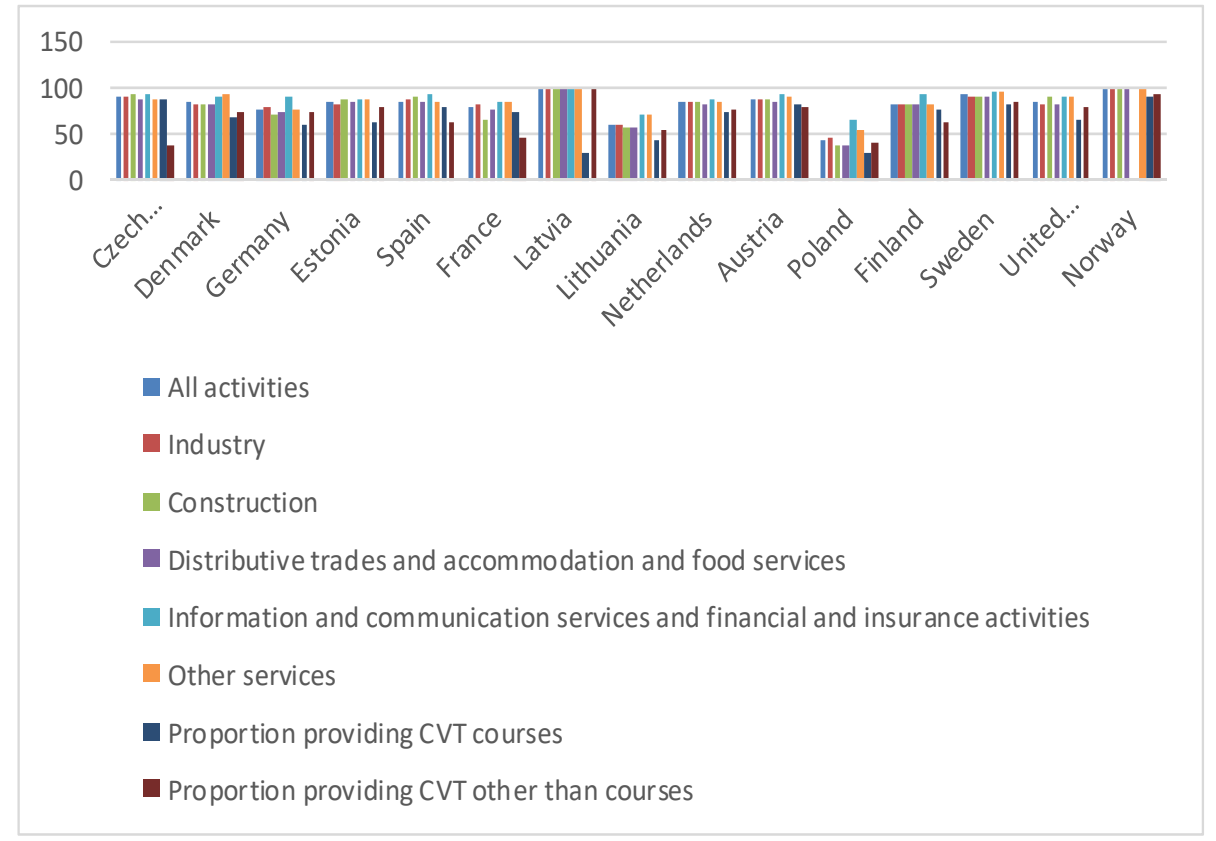

Fig. 5. Enterprises providing CVT activity and type of training

Source: author's calculations based on European Community Statistics Service

\subsection{Practice of vocational education financing in Georgia}

Promotion and development of vocational education is important for Georgia, as it provides facilitation of lifelong learning and plays the important role in formation of skilled workforce. Besides, this shall become one of the main factors in deal with unemployment, as requirement of skilled human recourses is typical for the developing countries and may become the main factor for inflow of foreign investments. A clear example for this are the investments of the South Korea to Vietnam, where the motivational factor for implementation of FDI have been considered skilled workforce. Appropriately, in case of Georgia, qualification may appear the decisive factor in making choice by investors. 
Besides, the deep and universal agreement of economic relations concluded with the European Community to some extent binds us to adopt labour market to EU market, what will be impossible without decrease of unemployment and professional development of employees.

In 2018 Georgia adopted the new law on vocational education which superseded the previous edition of 2007. This law determines its general goals and objectives including approximation of the vocational education system of Georgia to the single European educational area, ensuring of the compatibility with the integrated European vocational educational space and adaptation of vocational education to the existing or future requirements of the labour market and the preparation of an individual for employment and business activities, what will finally cause increase of productiveness in our country [40]. Besides, amount of funding and sponsored programmes are determined by Ordinance of the Government of Georgia N 244 issued in 2013. This Ordinance contains the following list of kinds of funding:

1. Voucher financing;

2. Financing of vocational educational programmes consisting of modules;

3. Programme financing;

4. Target programme financing

This normative act is being amended on annual basis in respect of quantity of specialities/programmes and amounts of their financing. Maximum amount of financing is 2250 GEL and the State finances vocational educational institutions founded as legal entities of public or private law and conducting the vocational educational programmes fixed by the legislation [41].

Financing of education in Georgia, not only vocational one lags behind the standards of the European Community. Besides, lack of information and insufficient researches prevent us from monitoring of this process. In 2018 about 44 million GEL was allotted for vocational education, while state budget was 12 milliard GEL. According to the discussed materials, financing of vocational education shall be at least about $1 \%$ to allow some correlation.

The diagrams provided here below contain amount of financing, quantity of vocational institutions according to the regions, sectoral analysis and number of teachers according to years. Also it should be noted that this information is rather outdated and poor, that is why, many matters remain unexamined.

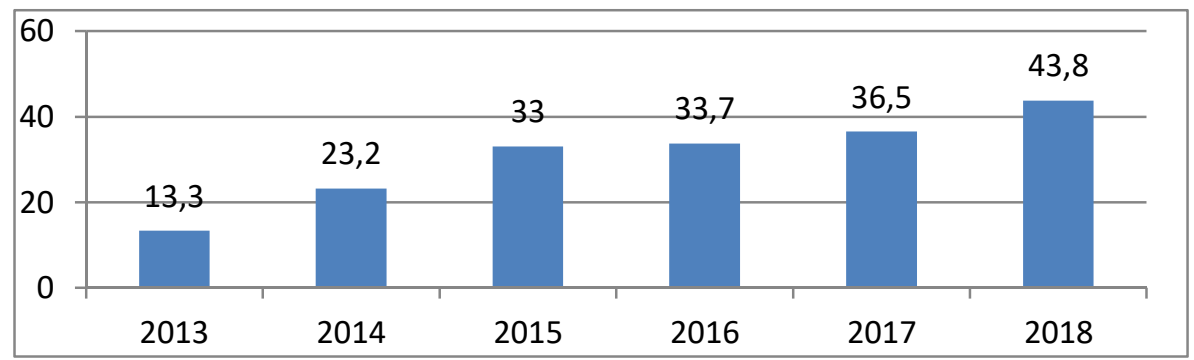

Fig. 6. Financing of vocational education according to years, mln GEL

Source: author's calculations based on Ministry of Science and Education, Report of Reform of Vocational Education, Georgia 2017-2018 


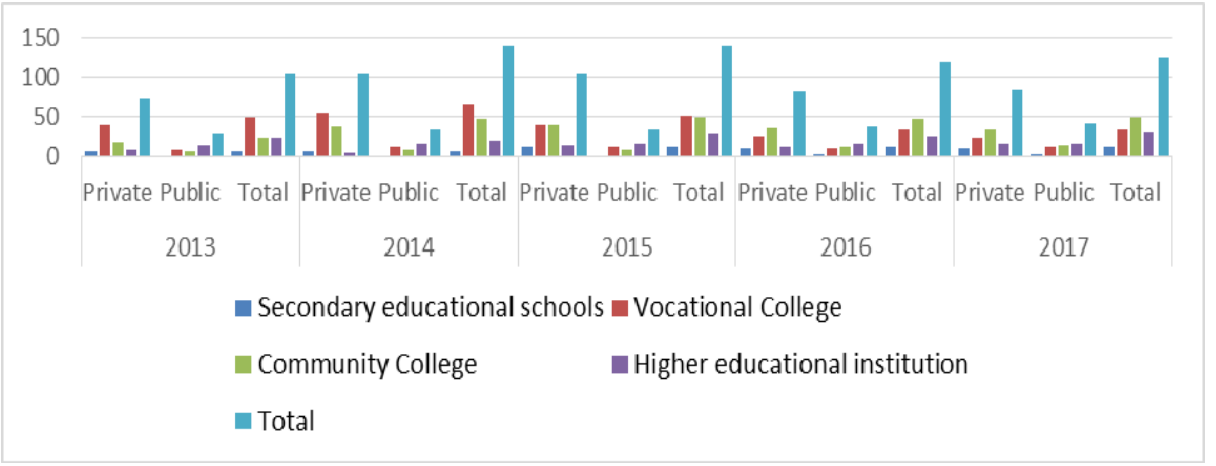

Fig. 7. Number of educational institutions, that conducted admission of students to vocational education programmes

Source: author's calculations based on Statistic Service of Georgia

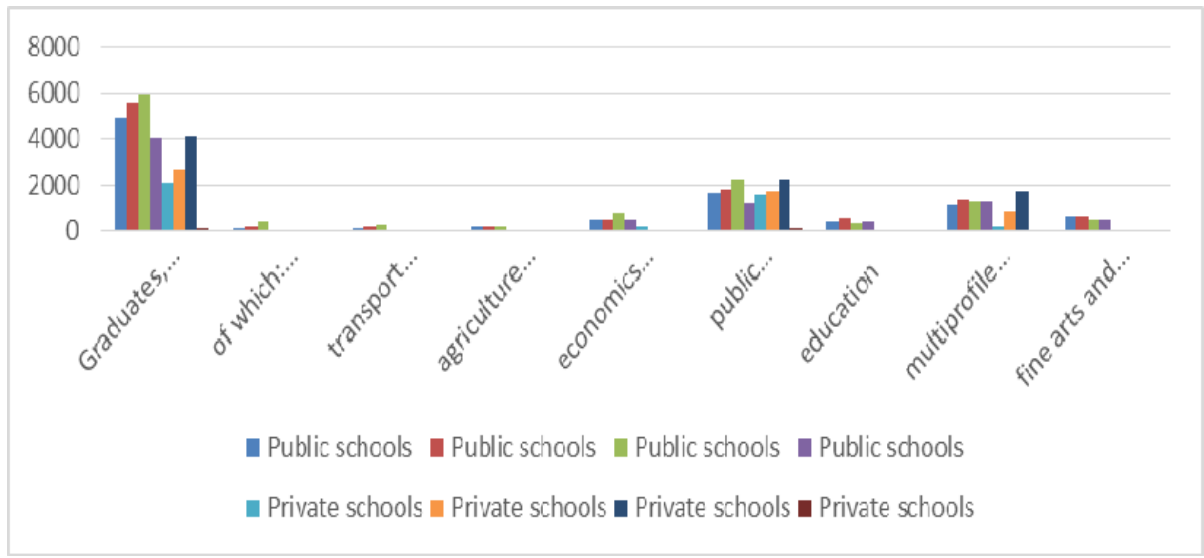

Fig. 8. Number of secondary vocational education graduates according specialities

Source: author's calculations based on Statistic Service of Georgia

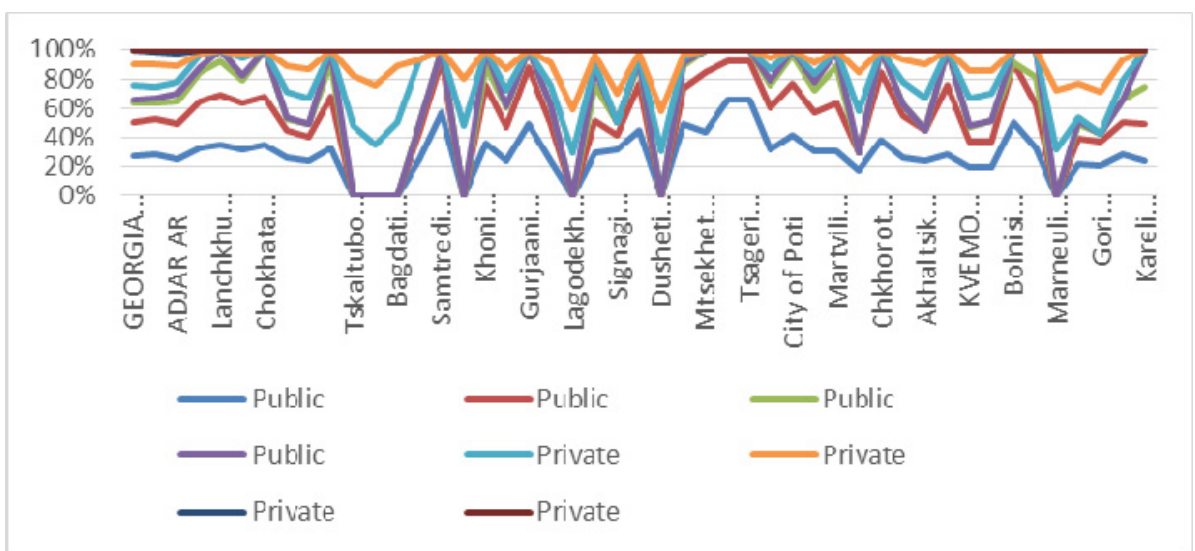

Fig. 9. Number of students accepted by vocational educational institutions, according to regions Source: author's calculations based on Statistic Service of Georgia 


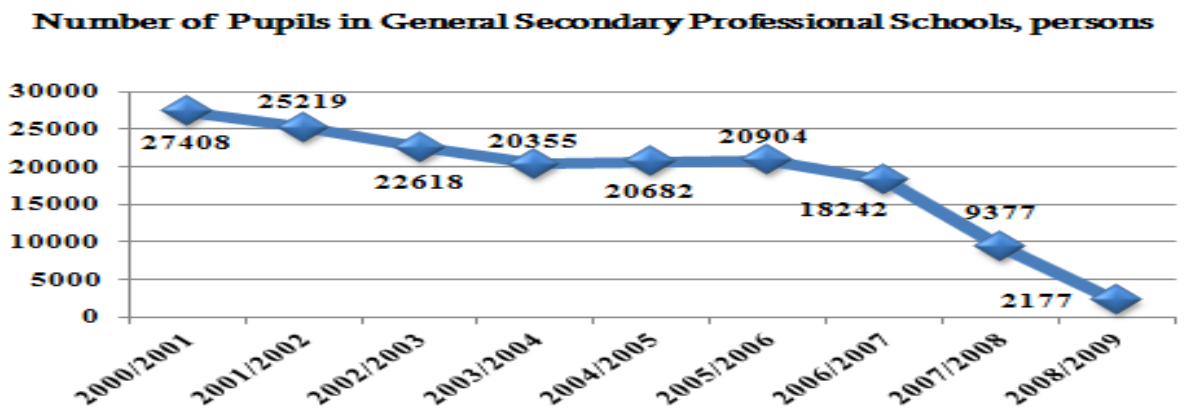

Fig. 10. Number of pupils of secondary professional schools

Source: author's calculations based on Statistic Service of Georgia

\section{Research Results}

Factually we cannot retrieve up-to-date information to determine number of students of vocational educational institutions in Georgia. Besides, there is not any mechanism assessing effectiveness of such institutions. No statistic information for the period after 2008 is available, neither exists a special agency analyzing this segment. On the one side, we have the developed legislative basis which shall provide approximation to the European standards (this aim is also fixed in the law), although it is not adopted to the current challenges in financial and organizational aspects. But most of scientists easily find correlation between rise of level of vocational education and productiveness, GDP and employment. On the one side, Georgia is attractive for investing what is proved with evaluations prepared by the International Credit Agency (Fitch, Doing Bussines, Moody), but we have not the thing which is extremely needed for the foreign and domestic investors - skilled labour force. Thus, the State shall upon legislative implementation determine the ways of determination of future demands of vocational education and its financing. Financing is progressing in Georgia, but it still averagely 8-10 times less than the same in the EU countries. As for Estonia, it is also the clear example, as in 2014 they allotted 108 million Euro. Besides, actually the EU countries provide annual researches of labour market and further draw up the actions plan. If we take for example Germany or Cedepof, they research and monitor vocational education market in the EU countries what allows those counties to exchange their experience and introduce the unified standards.

In case of Georgia, unemployment remains the main challenge at the governmental level. It is proved with the last years tend of its increase. These is enough strong relation between vocational education skill improvement and employment. In the most EU countries (it is of different kinds, but the same tend is apparent), but in Georgia it would not be proper to carry out such research, as we have not even minimum data required for such analysis , namely amount of costs (both for public and private financing), we cannot establish number of students studying in vocational institutions and above all, there is not a registry where we could retrieve the information of the proportion of employment of vocational institutions graduates in labour market. This is surely a complex problem which needs system solutions. Solution of this matter will play the important role in rise of competitiveness of labour market, what will promote further development of economy and employment level. 


\section{Conclusion}

The various countries of the world apply the different methods and mechanisms for financing of vocational education, but the countries try to keep this sphere in place, as it connects individuals, organizations, the State and it brings benefit for all three links. The world experience shows that financing of vocational education and its role for economy is surely important, but its implementation is often connected with complications which may be caused by socioeconomic and cultural factors of countries.

The countries differ in labour market scale, teaching quality, amount of financing. All these makes the countries to develop the models of financing of vocational education adopted to certain countries. That is why, in different countries amount and extent of financing may be divided between the State and the private sector. The EU countries trying to develop the unified standard, still use the different systems, as they rely on the historical experience and domestic researches, what proves complicacy of financing of vocational education. As for financing of vocational education and its effect on economy, such relation is recognized and proved with the researches. That is why, the countries try to make financing of vocational education rational and result-oriented. The mentioned cannot be provided without determination of labour market demands which requires systematic control. Just upon such supervision, the State shall determine market demands and needs, what will allow us to finance just the vocational sectors much in demand. This will promote rational spending of funds and will be effective.

Analysis of the international practice will promote more effective identification of the shortcomings in Georgia in this terms. Vocational education and its financing is very poor and lags behind the international standards. Rise of financing itself cannot be considered the step forward if we will not determine the expected results, what shall be done by the way of system monitoring of labour market. Lack of information and researches prevents us from planning the programmes of vocational continuing education, although it required inclusion of the various entities, ex. employers, unemployed, employees, employers' associations etc. Without such consideration this sector cannot be effectually planned and develop in Georgia, what will play the important role in development of economy of our country.

Proceeding from above, we shall conclude that rational determination of financing of vocational and continuing education remains one of priority challenges in any country, what positively effects employment and productiveness levels.

\section{References}

1. G. Abuselidze. Optimal Fiscal Policy - Factors for the Formation of the Optimal Economic and Social Models. Journal of Business and Economics Review, 3(1), 18-27, (2018)

2. G. Abuselidze, N. Devadze, T. Kakhidze. About One Mathematical Model of Project Management. In 2018 IEEE East-West Design \& Test Symposium (EWDTS), (2018, September). DOI: 10.1109/EWDTS.2018.8524622

3. G. Abuselidze, M. Mikeladze. The Role of Program Financing in the System of Higher Education (No. 4/2017). Institute of Economic Research (2017)

4. W. Arulampalam, et al. Work-related training and earnings growth for young men in Britain. Research in labor economics, 16, pp. 119-147, (1997)

5. R. Baker, J. Thompson. Innovation in general practice: is the gap between training and non-training practices getting wider? British journal of general practice, June 1995, 
45(395), 297-300, (1995). Retrieved from: http://www.ncbi.nlm.nih.gov/pmc/articles/PMC1239263/pdf/brjgenprac00019-021.pdf.

6. R.J. Barro, J.W. Lee. International comparisons of educational attainment. Journal of monetary economics, 32(3), 363-394. (1993). http://dx.doi.org/10.1016/03043932(93)90023-9.

7. R.J. Barro. Determinants of economic growth: a cross-country study. Cambridge, MA: MIT Press. (1998).

8. A. Bassanini, S. Scarpetta. The driving forces of economic growth: panel data evidence for the OECD countries. OECD journal: economic studies, 33(2). (2001). Retrieved from: http://www.oecd.org/economy/growth/18450995.pdf.

9. J. Benhabib, M.M. Spiegel. The role of human capital in economic development: evidence from aggregate cross-country data. Journal of monetary economics, October 1994, 34(2), 143-173. (1994). http://dx.doi.org/10.1016/0304-3932(94)90047-7.

10. R. Blundell, et al. Human capital investment: the returns from education and training to the individual, the firm and the economy. Fiscal studies, March 1999, 20(1), 1-23. (1999). http://dx.doi.org/10.1111/j.1475-5890.1999.tb00001.x.

11. H. J. Bodenhöfer. Probleme der Bildungsfinanzierung - Zum Stand der Diskussion, in: BRINKMANN, G. (Ed.): Probleme der Bildungsfinanzierung, Publications of the VereinfürSozialpolitik, GesellschaftfürWirtschafts- und Sozialwissenschaften, New Series, 146. Berlin, (1985). Retrieved from: http://www.cedefop.europa.eu/files/RR1_Kath.pdf.

12. A. Björklund. Evaluations of labour market policy in Sweden. International journal of manpower, 15(5), 16-31. (1994). http://dx.doi.org/10.1108/01437729410061429.

13. D. Cohen, M. Soto. Growth and human capital: good data, good results. Journal of economic growth, March 2007, 12(1), 51-76. (2007). http://dx.doi.org/10.1007/s10887007-9011-5.

14. M. Dickson, C. Harmon. Economic returns to education: what we know, what we don't know, and where we are going - some brief pointers. Economics of education review, $\begin{array}{llll}\text { December 2011, } & \mathbf{3 0}(6), & 1118-1122 . & \text { (2011). }\end{array}$ http://dx.doi.org/10.1016/j.econedurev.2011.08.003.

15. M. Dickson, S. Smith. What determines the return to education: an extra year or a hurdle cleared? Economics of education review, December 2011, 30(6), 20, (2011). Retrieved from: http://www.cedefop.europa.eu/files/4121_en.pdf.

16. K. Denny, et al. Education, earnings and skills: a multi-country comparison. London: Institute for Fiscal Studies. Working paper; 4(8). (2003). Retrieved from: http://www.ifs.org.uk/wps/wp0408.pdf.

17. P. J. Dolton, et al. The wage effect of YTS: evidence from YCS. Scottish journal of political economy, November 1994, 41(4), 444-453. (1994). http://dx.doi.org/10.1111/j.1467-9485.1994.tb01138.x.

18. R.P. Dorsett, et al. Economic benefits of lifelong learning. London: National Institute of Economic and Social Research. NIESR discussion References 49 paper; No 352. (2010). Retrieved from: http://www.niesr.ac.uk/pdf/300310_103442.pdf.

19. N. Gemmell. Evaluating the impacts of human capital stocks and accumulation on economic growth: some new evidence. Oxford bulletin of economics and statistics, February 1996, 58(1), 9-28. (1996). http://dx.doi.org/10.1111/j.14680084.1996.mp58001002.x. 
20. D. Goux, É. Maurin. Returns to firm-provided training: evidence from French workerfirm matched data. Labour economics, January, 7(1), 1-19. (2000). http://dx.doi.org/10.1016/S0927- 5371(99)00023-8, p. 22. Retrieved from: http://www.cedefop.europa.eu/files/4121_en.pdf.

21. W. Groot, et al. Returns to within-company schooling of employees: the case of the Netherlands. In: Lynch, L. (ed.). Training and the private sector. Cambridge, MA: National Bureau of Economic Research, NBER comparative labour markets series, 299-308. (1994). Retrieved from: http://www.nber.org/chapters/c8786.

22. E. A. Hanushek, D. Kim. Schooling, labour force quality and economic growth. National Bureau of Economic Research. NBER working paper; No 5399. (1995). Retrieved from: http://www.nber.org/papers/w5399.pdf.

23. J. J. Heckman. Schools, skills and synapses. Economic inquiry, July, 46(3), 289-324. (2008). http://dx.doi.org/10.1111/j.1465-7295.2008.00163.x,

24. T. Hempell. Do computers call for training? Firm-level evidence on complementarities between ICT and human capital. Mannheim: ZEW, Centre for European Economic Research. ZEW discussion paper; No 3-20. (2003). Retrieved from: http://ftp.zew.de/pub/zew-docs/dp/dp0320.pdf.

25. P. Jones. Are educated workers really more productive? Journal of development economics, February, 64(1), 57-79. (2001). http://dx.doi.org/10.1016/S03043878(00)00124-3.

26. W. Keller. Absorptive capacity: on the creation and acquisition of technology in development. Journal of development economics, April, 49(1), 199-227. (1996). http://dx.doi.org/10.1016/0304-3878(95)00060-7.

27. D. Krueger, K. B. Kumar. Skill-specific rather than general education: a reason for USEurope growth differences? Journal of economic growth, June, 9(2), 167-207. (2004). http://dx.doi.org/10.1023/B:JOEG.0000031426.09886.bd.

28. A. Leiponen. Competencies, innovation and profitability of firms. Economics of innovation and new technology, 9(1), 1-24. (2000). http://dx.doi.org/10.1080/10438590000000001.

29. Productivity is measured as value added per worker. Value added consists of profit and wages. Training increases both wages and productivity. The net result depends on the bargaining power of claimants: organisation claiming profits and workers claiming wages

30. Cedefop. Most studies do not record the type of training. Cedefop's literature review foundonly five studies explicitly examining initial VET's effects on organisation performance. Evidence points toa positive effect, but it is limited and weak. (2011).

31. Cedefop. Benefits of vocational education and training in Europe for people, organisations and countries, pp. 23-24, (2013). Retrieved from: http://www.cedefop.europa.eu/files/4121_en.pdf.

32. Financing of vocational education and training, Folkmar Kath, Vocational education and training - the European research field Background report - Volume I, p. 35. Retrieved from: http://www.cedefop.europa.eu/files/RR1_Kath.pdf.

33. Financing Technical and Vocational Education: Modalities and Experiences, This document was prepared by UNESCO in co-operation with the Industrial Occupations Promotion Centre of the German Foundation for International Development, pp. 9-10, Retrieved from: https://unevoc.unesco.org/fileadmin/user_upload/pubs/iug006e.pdf.

34. Calculations by the Federal Institute for Vocational Education and Training, VET Data Report Germany 2016/2017. 
35. European Center for Vocational Education, Review of Vocational Education System of Estonia, Retrieved from: http://www.cedefop.europa.eu/files/4155_en.pdf.

36. European Center for Vocational Education Development, Retrieved from: http://www.cedefop.europa.eu/files/4155_en.pdf.

37. European Community Statistics Service, Retrieved from: https://ec.europa.eu/eurostat/statistics-

explained/images/c/c9/Cost_of_CVT_courses_per_participant\%2C_2015_\%28PPS\%2 9_ET18_II.png.

38. European Community Statistics Service, Retrieved from: https://ec.europa.eu/eurostat/statisticsexplained/images/6/67/Enterprises_employing_IVT_participants\%2C_2015_\%28\%25 _of_all_enterprises\%29_ET18_II.png.

39. European Community Statistics Service, Retrieved from: https://ec.europa.eu/eurostat/statisticsexplained/images/b/bc/Enterprises_providing_CVT_by_NACE_Rev_2_activity_and_t ype_of_training\%2C_2015_\%28\%25_of_all_enterprises\%29_ET18_II.png.

40. Law of Georgia On Vocational Education, article 2. Retrieved from: https://matsne.gov.ge/document/view/4334842? publication=0.

41. Ordinance of the Government of Georgia N244, Retrieved from: https://matsne.gov.ge/ka/document/view/2021412.

42. Ministry of Science and Education, Report of Reform of Vocational Education, 20172018, Retrieved from: https://mes.gov.ge/content.php?id=8806\&lang=geo.

43. K. McCormick. Towards a lifelong learning society? The reform of continuing vocational education and training in Japan. Comparative Education. Jan 1;25(2):13349. (1989).

44. Statistic Service of Georgia, Retrieved from: http://www.geostat.ge/?action=page\&p_id=2101\&lang=geo.

45. J. S. Pischke. Continuous training in Germany. Journal of population economics, August 2001, 14(3), 523-548. (2001). http://dx.doi.org/10.1007/s001480000040.

46. Timmermann. Dieter "Costs and Financing of Dual Training in Gennany: Is there any Lesson for other Countries'!", mimeo, University of Bielefeld, 1993.

47. T. Zwick. Apprenticeship training in Germany - Investment or productivity driven? Zeitschrift für Arbeitsmarktforschung, 40(2/3), 193-204. (2007). http://doku.iab.de/zaf/2007/2007_2-3_zaf_zwick.pdf. 